its position, has a more southern stamp. This appears partly by Novaya Zemlya being much richer in species than Spitzbergen, of which species several occur which belong to families not represented on Spitzbergen, and partly by the vegetation of Novaya Zemlya being richer in individuals. At many places, especially in the more southerly parts of the land and the interior of the fiords, the ground is covered with thickly-matted plants, to which there is nowhere on Spitzbergen anything corresponding. Their closeness and variety of colour often awoke our surprise and astonishment. The phanerogamic vegetation of Novaya Zemlya connects itself by means of common species not only with that of Spitzbergen, but also with the floras of Arctic America and northern Norway, and that of the shores of the Gulf of Bothnia and the Asiatic Continent.

"The more southern character exhibited by the phanerogamic vegetation of Novaya Zemlya, as compared with that of Spitzbergen, is as good as absent in its marine algæ. The same dissimilarity is also apparent with regard to the fauna. The land fauna is more southern, the marine fauna is high Arctic. The most of the marine algæ known to exist at Spitzbergen are found at Novaya Zemlya, and of the species collected here there is cnly one that is wanting on the coasts of Spitzbergen.

"Of fresh-water algæ, mosses, and lichens, we have made considerable collections. Of musbrooms, on the contrary, we obtained very few. Either it was a bad mushroom year on Novaya Zemlya, or else, what is less probable, this class of plants is very sparingly distributed on these islands.

As on the coasts of Greenland and Spitzbergen, so in the parts of the Polar Sea we now visited, the surface of the sea at certain places which appear to be sharply defined is quite full of diatomacere. A belt of special richness we found on the north const of Norway, extending in an easterly direction from North Cape to the mouth of Tana Fiord ; another, less rich and of less extent, we found in the neighbourhood of the Samoyede peninsula.

"Through the researches of Th. von Heuglin, we bave already a good knowledge of the vertebrates of Novaya Zemlya. The attention of our zoologists has, however, theen directed to this group of animals, and by their observations our knowledge of them has been very considerably extended. This specially holds good of the birds.

Along the whole west coast south of Matotschkin Scharr, as weli in the open sea as in the fiords and sound where we sailed through and lay at anchor, dredging has been assiduously carried on. The rich collections thus made will certainly, when they are examined, afford a very complete idea of animal life in this region. Few species of animals were previously known as existing here, and as to the distribution of the different species along that extensive coast all information has hitherto been wanting.

"Anong the zoological work" a conspicuous, place is occupied by a rich insect collection by which the knowledge that we previously had of Novay a Zemlya's insect world will be very considerably extended. Formerly from this region only four or five species of insects were known. The expedition's collection consists of about 500 specimens, and includes numerous representatives of nearly all the orders of insects.

"Most important, however, in a zoological aspect, appear to me the numerous dredgings which were carried on in the Kara Sea, and which prove that in this sea there is, as has been already mentioned, abundant animal life of very various types. The collections made here are large, and must be specially valuable for zoological science as coming from a considerable region of the Polar Sea, of which the zoology is little known, but especially because this extent of sea exhibits in different tracts so considerable dissimilarities with respect to depth, content of salt in the water, \&c."

\section{BOTANICAL NOTES}

The Calcutta Botanical GaRdens.-Dr. King's report on the Royal Botanical Gardens, Calcutta, for the year ending March 3I, 1875 , to which we have recently referred (vol. xii. p. 54I), contains some interesting notes on the cultivation of useful plants, especially the Para rubber plant (Hevea brazilicnsis) and the Ipecacuanha (Cephalis ipecacuanha). With regard to the former, Dr. King is of opinion that the plants will not thrive in that part of India. Mr. Collins, in his report on the Caoutchouc plants, describes the Heveas as growing in their native country in situations where the heat is not generally ahove $87^{\circ} \mathrm{Fahr}$. in the afternoon, and below $74^{\circ}$ at night, and shows, on the authority of Wallace, that the temperature in the caoutchouc districts during three years only once reached to $95^{\circ}$, the greatest heat being about 2 P.M., when it ranges from $89^{\circ}$ to $94^{\circ}$, and never lower than $73^{\circ}$. The meteorological returns for Calcutta show a wide difference between the Brazilian and the Indian climates. Another Caoutchouc plant, however, the Vahea madagascariensis, Boj., a climbing apocyneous shrub, native of Madagascar, promises to thrive much better than the Hevica. The fact of the plant being of climbing habit militates considerably against its value as a cultivated plant, owirg to the difficulty in providing supports as well as in obtaining the caoutchouc. Never. theless, it is a kind highly valued in the English market, realising a price next to Para rubber. With regard to Ipecacuanha, which has been shown to require much care and attention as to soil and situation, we le arn that a number of sets of plants were put out during the early part of the year at different spots at low elevations in the Cinchona reserve at Sikkim; warm, well sheltered situations, with good virgin soil, were chosen. "Some of the plants thus put out were protected by the natural shade of the forest, others by a sloping thatch of grass. Until the arrival of the cold weather all went well, but the unusually low tem. perature that prevailed during that season was fatal to the majority of the plants." Dr. King further says that he is "driven reluctantly to the conclusion that it is doubtful whether ipecacuanha can be successfully cultivated as an out-door crop in Sik kim." Further trials, however, are to be made before its experimental cultivation is recommended to be abandoned.

Eucalyptus globulus bas had its share of attention in India, and without considering the question of the truth or otherwise of its reputed value, it is proved that althe ugh it grows quickly and with vigour on the Neilgherries and Khasia hills at 5,000 to $8,0 c 0$ feet above the sea, it cannot be induced to live even for a year or two in the hot plains of India. Dr. King's description of the fine old Banyan tree, "one of the greatest curiosities and ornaments of the place," will, we are sure, be read with interest. He says : "Although considerably damaged by the cyclone ot 1864, which carried away two of its largest arms, this fine tree continues to grow vigorously. It now covers an area of ground $8 \mathrm{co}$ feet in circumference ; its trunk girths $5 \mathrm{I}$ feet, and from its branches no fewer than I 70 aërial roots are sent down to the ground, some of them being more than ten feet in circumference. This fine old tree supports quite a colony of orchids, ferns, and creeping plants of about twenty distinct species, and gives shelter to innumerable birds. Its exact age is not known, but, considering how rapidly banyans grow, it probably dces not much exceed that of the garden, and is therefore less than a century."

Gum ARABIC. - In a recent number of the Revue des Scitnces Naturclles, Prof. Charles Martins, of Montpelier, draws attention to a peculiar mode of exudation of gum arabic from the Acacia verek of Senegal. On the authority of Schweinfurth, quoted in the "Pharmacographia," p. 206, it is stated that this tree, exclusively, yields the fine white gum of the countries bordering the Upper Nile, and especially of Kordofan. It is described as growing to a height of about twenty feet, and though the gum is one of the principal productions of the colony, being collected in large quantities by the Moors, who exchange it for European commodities, no notice occurs of any peculiarity in its formation or collection; indeed, it is stated that "the gum generally exudes from the trees spontaneously, in sufficient abundance to render wounding the bark superfluous. The Somali tribes of East Africa, however, are in the habit of promoting the outflow by making long incisions in the stem and branches of the tree. In Kordofan the lumps of gum are broken off with an axe, and collected in baskets." Prof. Martins shows that the exudation of the gum is often promoted by the growth of a species of Loranthus, his observations being founded on actual specimens of branches of the Acacia upon which the parasite had formed. In several instances the gum had exuded in a vermicular form always at the point of union of the parasite with the stock. This union of the two plants forms, as is usual with other Loranthaceous species, an irregular, gnarled-like protuberance, from which are given off both the branches of the Acacia and also of the Loranth, each of which is very distinct from the other, those of the Acacia being spiny and more slender than those of the parasite. Rather than this mode of exudation being rare, it would seem to be of frequent occurrence M. Martins considers the parasite to be a new species of Loranthus, for which he proposes the name of Loranthus sene. galensis, placing it near L. pextagonia, DC. 